\title{
Multi-criteria decision analysis for the optimal management of nitrate contamination of aquifers
}

\author{
Mohammad N. Almasri ${ }^{1}$, Jagath J. Kaluarachchi* \\ Department of Civil and Environmental Engineering and Utah Water Research Laboratory Utah State University Logan, Utah 84322-8200, USA
}

Received 3 January 2004; revised 14 September 2004; accepted 14 October 2004

\begin{abstract}
We present an integrated methodology for the optimal management of nitrate contamination of ground water combining environmental assessment and economic cost evaluation through multi-criteria decision analysis. The proposed methodology incorporates an integrated physical modeling framework accounting for on-ground nitrogen loading and losses, soil nitrogen dynamics, and fate and transport of nitrate in ground water to compute the sustainable on-ground nitrogen loading such that the maximum contaminant level is not violated. A number of protection alternatives to stipulate the predicted sustainable on-ground nitrogen loading are evaluated using the decision analysis that employs the importance order of criteria approach for ranking and selection of the protection alternatives. The methodology was successfully demonstrated for the Sumas-Blaine aquifer in Washington State. The results showed the importance of using this integrated approach which predicts the sustainable on-ground nitrogen loadings and provides an insight into the economic consequences generated in satisfying the environmental constraints. The results also show that the proposed decision analysis framework, within certain limitations, is effective when selecting alternatives with competing demands.
\end{abstract}

(C) 2004 Elsevier Ltd. All rights reserved.

Keywords: Nitrate; Non-point source pollution; Decision analysis; Optimization; Genetic algorithm; Artificial neural network; Land use

\section{Introduction}

Public concerns over ground water quality have grown significantly in recent years and have focused increasingly on agriculture as a source of nitrate pollution of ground water. Nitrogen is a vital nutrient to enhance plant growth. Nevertheless, when nitrogen-rich fertilizer and manure applications exceed the plant demand and the denitrification capacity of soil, nitrogen can leach to ground water usually in the form of nitrate (Meisinger and Randall, 1991). In general, agricultural practices result in non-point source pollution of ground water and the effects of these practices accumulate over time (Schilling and Wolter, 2001). Non-point sources include fertilizer, dairy farms, manure

\footnotetext{
* Corresponding author. Address: Utah Water Research Laboratory, Utah State University, Logan, UT 84321, USA. Tel.: +1 4357973918.

E-mail address: jkalu@cc.usu.edu (J.J. Kaluarachchi).

${ }^{1}$ Present address: Water and Environmental Studies Institute, An-Najah National University, Nablus, Palestine.
}

application, and leguminous crops. Harter et al. (2002) showed that manure application has a significant effect on the nitrogen content of soil especially in areas with high densities of dairy farms. Elevated nitrate concentrations in ground water are common around dairy operations, barnyards, and feedlots. Fertilizer applications on row crops are considered to be a major source of non-point nitrate leaching to ground water particularly in sandy soils (Hubbard and Sheridan, 1994). Point sources of nitrogen such as septic tanks and dairy lagoons are shown to contribute to nitrate pollution of ground water (Erickson, 1992; MacQuarrie et al., 2001). Due to the presence of nitrogen sinks in soils that provide nitrate to ground water together with denitrification of nitrate in ground water, there is a sustainable on-ground nitrogen loading that the subsurface can handle without exceeding the maximum contaminant level (MCL) of $10 \mathrm{mg} / \mathrm{L}$ as $\mathrm{NO}_{3}-\mathrm{N}$ (US Environmental Protection Agency, 2000). This sustainable loading, which can also be called as the optimal loading, is 
generally a function of the total on-ground nitrogen loading, soil nitrogen dynamics, and the fate and transport of nitrate in ground water along with many other parameters pertaining to soil and aquifers.

The increasing evidence of nitrate contamination of ground water beyond the MCL has intensified the need for developing protection alternatives such as the restriction of fertilizer use and manure applications. Through the adoption of these alternatives, it is possible to protect ground water quality by reducing the nitrate occurrences in ground water. Identification of areas with heavy nitrogen loadings from point and non-point sources is important for land use planners and environmental regulators. Once such high-risk areas have been identified, preventive alternatives can be implemented to minimize the risk of nitrate leaching to ground water (Tesoriero and Voss, 1997; Ramanarayanan et al., 1998; Yadav and Wall, 1998).

As such, it is essential to introduce an effective protection alternative to an area under threat by nitrate pollution. This step is commonly achieved by maintaining the on-ground nitrogen loadings below the sustainable loadings that satisfy the MCL constraint at selected receptors. In introducing the protection alternatives, one should ask; where should these alternatives be imposed? What are the maximum on-ground nitrogen loadings that should not be exceeded in order to satisfy the MCL limit? Of course, if the current on-ground nitrogen loadings do not exceed the sustainable loadings, then protection alternatives are not needed and vice versa. Perhaps the most important point in evaluating the success of the protection alternatives is whether these alternatives will result in a decrease in nitrate below the MCL or not and if so, how long this will take and how much does it cost? For these reasons, a protection alternative will be successful if it reduces the on-ground nitrogen loading to less than the sustainable loading.

Protection alternatives implicitly expose conflicting objectives. For example, the main goal of a protection alternative is to reduce the nitrate concentrations below the MCL. On the other hand, a protection alternative should minimize the economic losses incurred from their implementation. In general, once the sustainable loading is determined for a particular region perhaps through an optimization framework, then different protection alternatives can be evaluated to meet this requirement depending on the nitrogen sources present in the region. These conflicting goals can yield different economic consequences and different prioritization schemes based on practicality and applicability of each proposed alternative. Therefore, a sound management decision model is essential to balance between competing economic and environmental goals and a multi-criteria decision analysis may be needed to prioritize the proposed protection alternatives.

In the light of the above discussion, the questions and concerns to be addressed by this work are (i) what is the spatial distribution of sustainable on-ground nitrogen loading that is necessary to maintain the nitrate concentration below the MCL; (ii) which protection alternatives should be considered to meet this sustainable loading if the existing loading is too high; (iii) what are the individual economic costs incurred due to the adoption of each protection alternative; and (iv) how to balance between the competing environmental and economic goals and how to prioritize the protection alternatives accordingly.

To address the above questions, a decision analysis framework is developed to determine the most effective and the least-costly protection alternative for a given ground water system. The proposed methodology addresses the issue of aquifer restoration by keeping the on-ground nitrogen loadings below the sustainable loading, such that the nitrate concentrations at specific receptors are below the MCL. The methodology integrates models of fate and transport of nitrate and soil nitrogen dynamics with an optimization and a multi-criteria decision analysis. In this work, the proposed methodology is developed and its applicability will be demonstrated for the Sumas-Blaine aquifer of Washington State where the major sources of onground nitrogen loadings are from agricultural fertilizers and manure applications (Almasri, 2003; Almasri and Kaluarachchi, 2004a-c).

\section{Methodology}

Fig. 1 depicts a general illustration of the proposed methodology to compute the sustainable on-ground nitrogen loading for a particular region. It integrates on-ground nitrogen loading, fate and transport in ground water, and soil nitrogen dynamics with an optimization module, subject to the constraint of maintaining concentrations below the MCL. Once the sustainable loading for the given region is computed, then a series of protection alternatives will be assessed through the decision analysis model subject to a set of decision criteria. The results of the decision analysis will provide the best protection alternative that satisfies the decision criteria while maintaining the on-ground loading below the sustainable loading.

\subsection{Nitrogen sources and simulation of nitrate contamination}

The overall conceptual model relating the on-ground nitrogen loading to the concentration in ground water is shown in Fig. 2 (Almasri, 2003; Almasri and Kaluarachchi, 2004a,c). The proposed conceptual model is comprehensive as it considers the spatial and temporal distribution of onground nitrogen loading from different combinations of land uses and nitrogen sources present in a study area, soil nitrogen dynamics, and finally the fate and transport processes in ground water due to nitrate leaching from the soil. The complexity of this conceptual model arises from the high spatial and temporal variability of nitrogen sources and related land use practices, dissimilar source types, many 


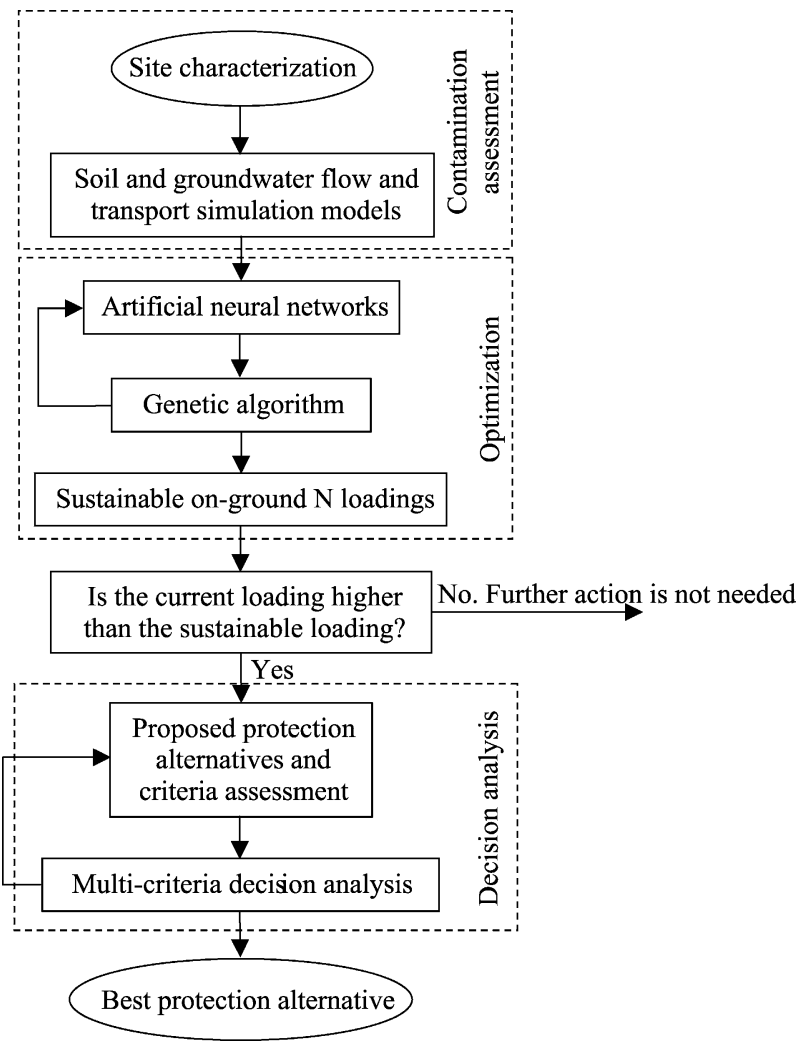

Fig. 1. A flow chart describing the proposed methodology integrating the on-ground nitrogen loading, soil nitrogen dynamics, fate and transport, optimization, and decision analysis.

geochemical reactions of nitrogen in the soil, and the various fate and transport processes in ground water.

The first step in this modeling framework is the estimation of the spatial and temporal distribution of on-ground nitrogen loadings (see Fig. 2). To better understand and assess the distribution of nitrate leaching, the on-ground nitrogen loadings can be computed using the National Land Cover
Database (NLCD) as prepared by the US Geological Survey (Almasri and Kaluarachchi, 2004a-c). The NLCD grid has 21 different land use classes describing the entire US. In general, the main nitrogen sources in agricultural watersheds include dairy and poultry manure, dairy lagoons, applications of fertilizers on agricultural fields and lawns, atmospheric deposition, irrigation with nitrogen-contaminated ground water, septic tanks, and nitrogen fixed by legumes (Almasri and Kaluarachchi, 2004a-c). The abovementioned nitrogen sources are spatially allocated using the NLCD except for septic tanks and dairy lagoons where GIS point shapefiles are utilized to assign the corresponding loadings (Almasri and Kaluarachchi, 2004a).

When nitrogen enters the soil, it undergoes many biochemical transformations before leaching to ground water mostly as nitrate (see Fig. 2). Many mathematical models are available to simulate soil nitrogen transformations. Detailed illustration of available models can be found in Ma and Shaffer (2001) and McGechan and Wu (2001). In this work, a soil nitrogen model was developed following the framework outlined in the Nitrate Leaching and Economic Analysis Package (NLEAP) (Shaffer et al., 1991). The motivations and the reasons for developing a separate soil nitrogen model rather than using an existing model are (Almasri, 2003; Almasri and Kaluarachchi, 2004a): (i) to incorporate agricultural, domestic, and natural sources of nitrogen in the model; (ii) ease of data manipulation using the NLCD grid and flexible output processing using GIS; and (iii) the ability to integrate the overall model with the proposed fate and transport model of nitrate in ground water. The final output from the soil nitrogen model is the nitrate leaching to ground water.

The development of the nitrate fate and transport model follows the simulation of the ground water flow system. This is a necessary step to obtain the potentiometric head distribution across the model domain, saturated thickness,

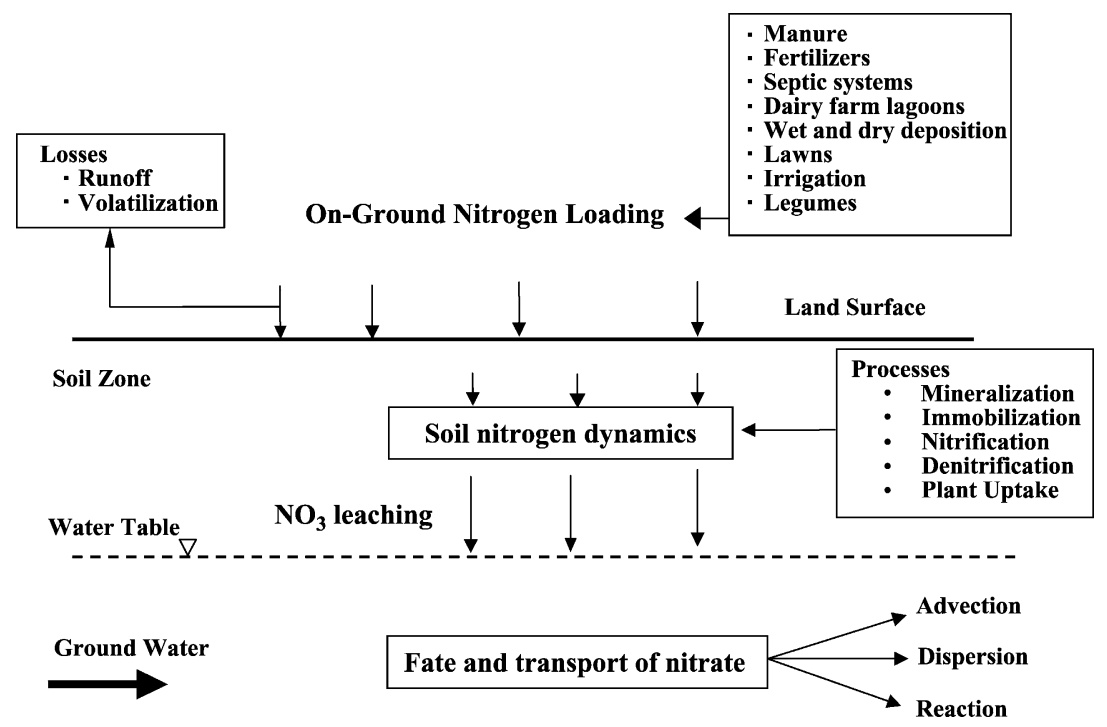

Fig. 2. Schematic describing the integrated modeling framework to predict the nitrate concentration in ground water. 
fluxes across cell interfaces in all directions, and locations of flow rates of the various sources and sinks. The advectiondispersion-reaction transport equation is thereafter solved for ground water with first-order irreversible rate reactions.

\subsection{Optimization}

The purpose of the optimization is to determine the sustainable on-ground nitrogen loading that satisfies the major constraint of maintaining nitrate concentrations at selected receptors below the MCL. The decision variables are the annual on-ground nitrogen loadings from agricultural fertilizers and manures at the selected drainages. Although other nitrogen sources and land uses are present in a typical watershed comprised of different drainages, management intervention to control nitrogen pollution can be implemented readily with agricultural fertilizers and manure. Therefore, these two decision variables have been selected for the analysis. It is further assumed that the onground loading of nitrogen in each drainage is spatially uniform in areas where agriculture and dairy farming are practiced (this assumption is discussed in Section 5). In other words, each drainage of interest in a large watershed is assigned two decision variables (uniform nitrogen loadings) pertaining to fertilizers and manure. The sustainable onground nitrogen loadings correspond to the maximum loading (the upper bound) that the aquifer can sustain without exceeding the MCL at specified receptors. Symbolically, the objective function and constraints can be stated as

$\operatorname{Max} \Gamma=\delta_{\mathrm{M}} \sum_{i=l}^{\lambda} \mathrm{NM}_{i}+\delta_{\mathrm{F}} \sum_{i=l}^{\lambda} \mathrm{NF}_{i}$

subject to

$C_{k}^{t} \leq \mathrm{MCL}$ for $k=1, \ldots, Z$

where $\Gamma$ is the objective function to be maximized (lbs); $\mathrm{NM}_{i}$ is the sustainable annual manure loading for drainage $i$ (lbs); $\mathrm{NF}_{i}$ is the sustainable annual agricultural fertilizer loading for drainage $i(\mathrm{lbs}) ; \lambda$ is the number of the selected drainages; $\delta_{\mathrm{M}}$ and $\delta_{\mathrm{F}}$ are weighting coefficients for manure and fertilizer loadings, respectively $\left(\mathrm{L}^{0}\right)$; and $C_{k}^{t}$ is the maximum monthly nitrate concentration, $(\mathrm{mg} / \mathrm{L})$, at the last year of the simulation period, $t$, at receptor $k$; $z$ is the number of receptors. In Eq. (1), the values of $\delta_{\mathrm{M}}$ and $\delta_{\mathrm{F}}$ reflect the preference of the decision-maker in maximizing the manure or fertilizer loadings. Once the vectors of sustainable loadings, $\mathrm{NM}_{i}$ and $\mathrm{NF}_{i}$, are determined, these are compared to the vectors of existing loadings. If, for a specific drainage, the sustainable loadings are greater than the existing ones, then protection alternatives are not needed; otherwise, management alternatives are introduced accordingly and evaluated as shown in Fig. 1.

The proposed optimization approach utilizes genetic algorithms (GA). In general, GA requires many objective function evaluations. The simulation model is used at each time the objective function is evaluated and therefore, the search for the optimal solution may become time-consuming. Researchers have handled this situation in several ways among which is the use of an artificial neural network (ANN) as a proxy to the numerical model to expedite the process of evaluating the objective function (Morshed and Kaluarachchi, 1998; Aly and Peralta, 1999). Once the models of soil nitrogen dynamics and fate and transport in ground water are developed (based on Fig. 2), the ANN can be trained and tested using patterns generated from these models. The ANN picks the on-ground nitrogen loadings from manure and fertilizers for the selected drainages and predicts the corresponding nitrate concentrations at the specified receptors. In essence, the ANN replaces the nitrogen transformations in the soil and the fate and transport processes in ground water as depicted in Fig. 2.

Unlike the traditional optimization approaches, constraints in GA cannot be incorporated explicitly but implicitly using the penalty functions (Goldberg, 1989). In this case, the following penalty function is considered

$\varsigma=-\Omega \sum_{k=1}^{z}\left(C_{k}^{t}-C_{\mathrm{MCL}}\right)^{2}$ for $C_{k}^{t}>C_{\mathrm{MCL}}$

and

$\varsigma=0$ for $C_{k}^{t} \leq C_{\mathrm{MCL}}$

where $\varsigma$ is the penalty function; $\Omega$ is a commensuration coefficient that will be identified throughout GA simulations, and $z$ is the number of receptors. Detailed illustrations of ANN and GA concepts are available in Haykin (1994) and Goldberg (1989), respectively.

\subsection{Decision analysis}

The choice of an alternative from a set of alternatives is difficult if these alternatives are non-dominated for a given set of decision criteria. For an alternative to be dominant, it should be the best in terms of all decision criteria. Since the decision criteria developed in this work reflect both economic costs as well as environmental constraints, it is anticipated that no single alternative will be dominant. This condition necessitates the use of a multi-criteria decision analysis to prioritize the protection alternatives. In general, multi-criteria decision analysis evaluates a utility that expresses a decision-maker's outcome preference in terms of multiple criteria. A criterion is a characteristic of the protection alternatives that the decision-maker considers important. In this work, a multi-criteria decision analysis methodology that is based on the importance order of criteria (IOC) is adopted.

The IOC method (Yakowitz et al., 1993) is conceptually simple and provides the decision-maker with clear evidence if one alternative is strongly dominant over another. The IOC method is easy to program and provides rational 
results. The method relies on defining the best and worst total utilities of the alternatives through the ranking of the decision criteria for each alternative. The best total utility of an alternative is computed via maximizing the expected utility function, $U_{j}$, as follows

$U_{j}=\sum_{i=1}^{m} w_{i} v_{i j}$

where $m$ is the number of criteria of alternative $j$; $v_{i j}$ is the value of $j$ th alternative with respect to the $i$ th criterion; and $w_{i}$ is the weight assigned to criterion $i$. The maximization of the objective function in Eq. (5) is subject to the following constraints

$w_{1} \geq w_{2} \geq \cdots \geq w_{m}$

$\sum_{i=1}^{m} w_{i}=1$

$w_{m} \geq 0$

The first constraint defines the ranking of the importance of the criteria. The second and third constraints are the scaling and the weight non-negativity constraints. Likewise, the lowest total utility is found by minimizing the objective function given in Eq. (5) in the above linear program instead of maximizing it. The minimum and maximum objective functions determine the minimum and maximum total utility possible for any weight combination as far as the constraints are met. The two linear programs must be solved for each alternative under consideration. However, Yakowitz et al. (1993) showed that these linear programs can be solved in a closed form as discussed next. Let $k=$ $1, \ldots, m$, then $S_{k j}$ can be defined such that

$S_{k j}=\frac{1}{k} \sum_{i=1}^{k} v_{i j}$

Let $\mathrm{BU}_{j}$ and $\mathrm{WU}_{j}$ indicate the values of the optimal objective function to the best and worst total utilities, respectively, then

$\mathrm{BU}_{j}=\max \left\{S_{k j}\right\}$

and

$\mathrm{WU}_{j}=\min \left\{S_{k j}\right\}$

An alternative $k$ dominates alternative $j$ with the given importance order of criteria if $\mathrm{WU}_{k} \geq \mathrm{BU}_{j}$. However, if the computation of the best and worst total utilities did not yield a complete ranking of the alternatives, then the best and worst total utilities for each alternative are averaged out and the alternatives are ranked up in a descending order of these averages. In general, the criterion values are linearly scaled between 0 and 1 where the maximum value of a decision criterion corresponds to 1. Detailed illustration of the IOC method is available in Yakowitz et al. (1993).

\subsection{Protection alternatives}

As discussed earlier, the protection alternatives are assumed to be applied to areas that use agricultural fertilizers and produce dairy manure. The protection alternatives considered in the analysis are as follows;

Dairy herd size reduction. Since manure loading is a function of dairy herd size, downsizing the dairy herd is apparently the most straightforward and effective option that minimizes manure loading (Davis et al., 1999). However, such an option implies serious economic and political ramifications that may prohibit its adoption in some watersheds.

Manure composting/exporting. Manure exporting is a viable alternative since it does not involve herd size reduction. In order for manure to be exported and transported, it should be composted. Composting is the aerobic decomposition of organic matter by certain microorganisms such as bacteria that consume oxygen and use nutrients such as carbon, nitrogen, phosphorus, and potassium as they feed on the organic waste. Since carbon dioxide and water vapor escape during this process, the resulting compost can be approximately half the volume and weight of the original material (Pace et al., 1995).

Improve dairy cow diet. Many dairy producers overfeed crude protein to support high levels of milk production. However, this practice results in excessively high presence of nitrogen in the excrement. The protein that is not used for milk production or maintenance and growth is excreted as urea or organic-N. Van Horn (1992) showed that when cows were precisely fed to meet the National Research Council recommendations (NRC, 1989) through a balanced diet consisting of rumen degradable and undegradable protein, the nitrogen content in manure decreased by $14 \%$.

Reducing nitrogen fertilizer application rates. Since the fertilizer application on agricultural areas has been recognized as a main source of nitrate contamination of ground water, a reduction in the nitrogen fertilizer application rate is an efficient option (Yadav and Wall, 1998). However, excessive reductions in fertilizer applications may produce a decrease in crop yield causing serious economic consequences to the farmers and the local community.

\subsection{Decision criteria}

The proposed methodology introduces five main categories of decision criteria and these are (i) cost incurred from implementing the protection alternative; (ii) satisfaction of the MCL constraint; (iii) on-ground nitrogen loading and nitrogen losses; (iv) net nitrogen build-up in the soil and nitrate leaching; and (v) nitrate build-up in ground water and nitrate flux to surface water. Table 1 summarizes the decision criteria, the corresponding acronyms, and criterion categories. Each protection alternative is appraised for these decision criteria by computing the on-ground nitrogen loadings, utilizing the soil and ground water nitrate fate 
Table 1

Summary of the decision criteria, corresponding acronyms, and criterion category

\begin{tabular}{|c|c|c|}
\hline Description & Acronym & Criterion category \\
\hline Summation of concentration deviations above MCL (mg/L) & SCD & Maximum contaminant level \\
\hline Number of receptors exceeding MCL (-) & EMCL & Maximum contaminant level \\
\hline Net cost $(\$)$ & COST & Economic-cost \\
\hline Cost per unit concentration reduction $(\$ / \mathrm{mg}$ per $\mathrm{L})$ & CPCR & Economic-cost \\
\hline Nitrate buildup in ground water (lbs) & NBGW & Environmental-ground water \\
\hline Cumulative nitrate flux to surface water (lbs) & NFSW & Environmental-surface water \\
\hline Nitrate leaching (lbs) & NL & Environmental—soil \\
\hline Nitrate buildup in the soil (lbs) & NBS & Environmental—soil \\
\hline Ammonium buildup in the soil (lbs) & ABS & Environmental—soil \\
\hline Organic nitrogen build-up in the soil (lbs) & OBS & Environmental—soil \\
\hline Total nitrogen build-up in the soil (lbs) & TNBS & Environmental—soil \\
\hline Total on-ground nitrogen loading (lbs) & OGNL & Environmental-on-ground \\
\hline On-ground nitrogen runoff losses (lbs) & OGRL & Environmental-on-ground \\
\hline On-ground nitrogen volatilization losses (lbs) & OGVL & Environmental-on-ground \\
\hline
\end{tabular}

and transport models and an economic cost model. The problematic decision criteria are those pertinent to the costs of alternatives. The following subsections provide explanations for the economic cost and MCL constraint criteria.

MCL constraint criteria. Two decision criteria were considered in assessing the effectiveness of the protection alternatives in satisfying the MCL constraints. The first is the summation of positive concentration deviations, SCD, after introducing a protection alternative. SCD is defined as follows

$\mathrm{SCD}=\sum_{k=1}^{z}\left(C_{k}-10\right)$ for $C_{k}>10$

where $C_{k}$ is the maximum monthly nitrate concentration, $(\mathrm{mg} / \mathrm{L})$, at the end of the simulation period at receptor $k$, and $z$ is the number of nitrate receptors. The second decision criterion in this category, EMCL, considers the total number of receptors with nitrate concentrations exceeding the MCL.

Cost criteria. Two cost criteria were developed. The first criterion is the cost incurred from adopting a specific protection alternative, COST, and represents the present discounted cost of the protection alternative. COST is defined as follows (Newman, 1976)

$\operatorname{COST}=C_{\text {net }}\left[\frac{(1+i)^{t}-1}{i(1+i)^{t}}\right]$

where $i$ is the market interest rate; $t$ is the length of the planning period, and $C_{\text {net }}$ is the annual cost incurred from adopting a specific protection alternative considering both costs and benefits. A simple cost model can be developed using a spreadsheet to compute COST. The second criterion introduces the cost per unit nitrate concentration reduction, CPCR, and is defined as follows

$\operatorname{CosT}=\left[\frac{\mathrm{COST}_{i}-\mathrm{COST}_{0}}{\mathrm{AC}_{i}-\mathrm{AC}_{0}}\right]$ where $\operatorname{COST}_{0}$ and $\operatorname{COST}_{i}$ are the net costs incurred from the do nothing alternative and the $i$ th alternative, respectively; and $\mathrm{AC}_{i}$ and $\mathrm{AC}_{0}$ are the average receptor concentrations corresponding to the $i$ th and the do nothing alternatives, respectively. $\mathrm{AC}_{i}$ is defined as

$\mathrm{AC}_{i}=\frac{1}{z} \sum_{k=1}^{z} C_{k}^{i}$

where $C_{k}^{i}$ is the simulated nitrate concentration at receptor $k$ due to the $i$ th protection alternative. CPCR evaluates the cost effectiveness of a specific protection alternative and provides information on how resources are being employed to reduce the nitrate contamination.

\section{Demonstration example}

This section evaluates the applicability and practicability of the proposed methodology for the optimal management of nitrate contamination of ground water in an agriculturedominated watershed. The Sumas-Blaine aquifer of Washington State is considered for the demonstration of the methodology for a 10-year management restoration period.

\subsection{Site description}

Sumas-Blaine aquifer (see Fig. 3) is the principal surficial aquifer in the Nooksack Watershed in Whatcom County located in the northwest corner of Washington State (Almasri and Kaluarachchi, 2004a,c). This aquifer is used for domestic, agricultural, and industrial purposes and occupies an area of about 150 miles $^{2}$. Most of the soils in the study area are categorized as well-drained. The water table is shallow, typically less than $10 \mathrm{ft}$, but exceptions occur near the City of Sumas where the depth to the water table exceeds $50 \mathrm{ft}$ and depths exceed $25 \mathrm{ft}$ near the eastern part of the aquifer (Tooley and Erickson, 1996). The geology of the aquifer consists of three major geologic layers and two 


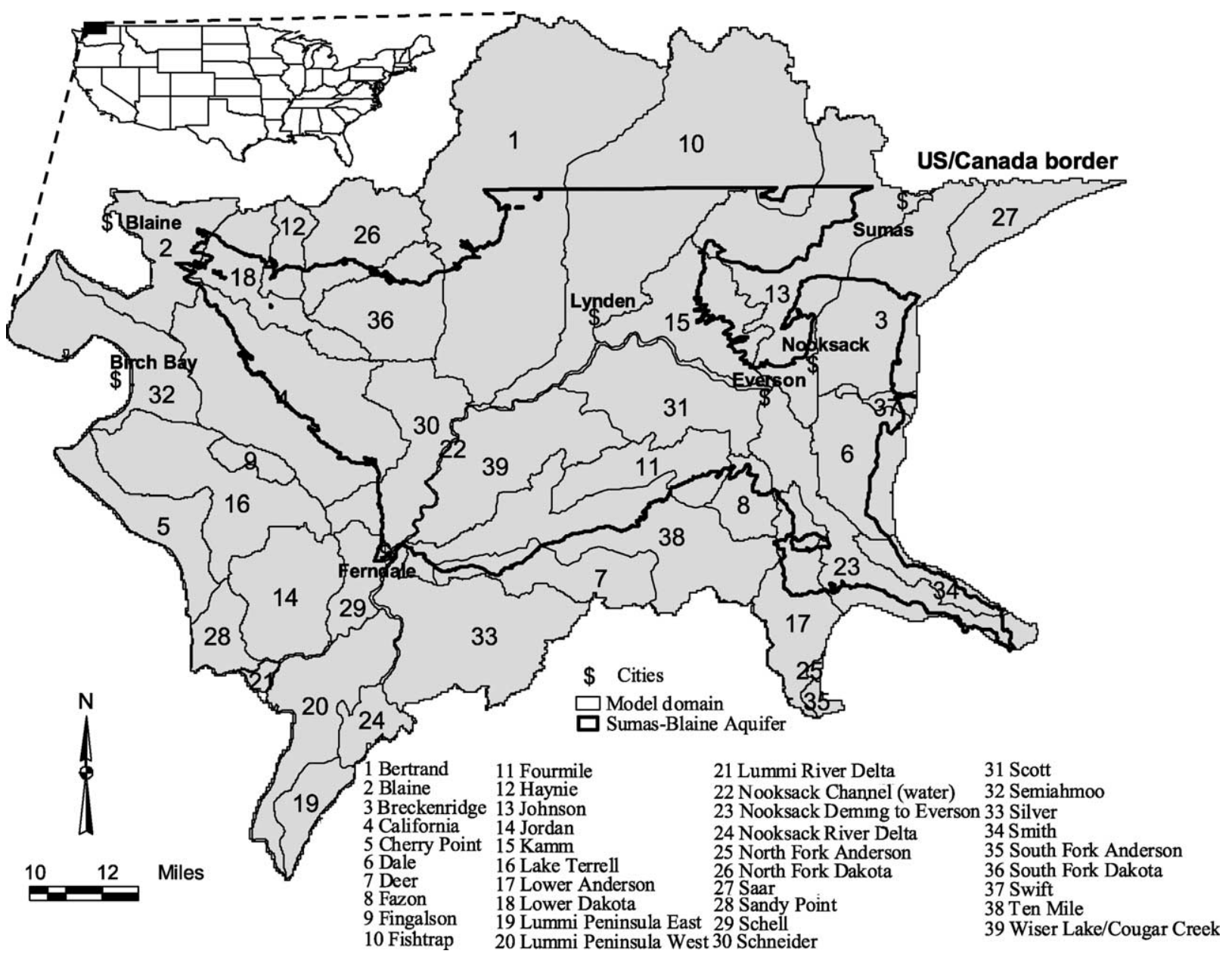

Fig. 3. The physical layout of the study area consisting of the Sumas-Blaine aquifer in Washington State and the different drainages.

confining units. The major layers are the Sumas layer, the Everson-Vashon fine-grained unit, and the EversonVashon coarse-grained unit (Kemblowski and Asefa, 2003b). The Sumas layer is the main productive layer and the most vulnerable to nitrate contamination (Almasri, 2003). Much of the ground water extraction and nitrate contamination occur in this layer. The Sumas layer is composed mainly of stratified sand and gravel outwash and the coarse-grained alluvium of the Nooksack and Sumas Rivers. The Sumas layer covers most of the study area except in the northwestern, southwestern, and central eastern parts. The Everson-Vashon fined-grained layer is a semi-confining unit composed of thick accumulation of unsorted clay and sandy silt with some local coarse-grained lenses. Typically this layer is more than $100 \mathrm{ft}$ thick and restricts hydraulic connectivity between the overlying Sumas layer and the underlying Everson-Vashon coarsegrained layer. Precipitation ranges from over 60 in. per year in the northern uplands to about $40 \mathrm{in}$. per year in the lowlands. Recharge to the aquifer is largely due to the infiltration of precipitation and irrigation.

The actual area considered in this work is larger than the boundaries of the Sumas-Blaine aquifer and includes parts of Canada (see Fig. 3). One reason for this larger area is that there is a substantial manure application on berry plantations located in the Canadian side (Mitchell et al., 2003). Since the ground water flow is from north to south towards the Nooksack River, the nitrogen-rich manure application in the Canadian side has a major influence on ground water quality in the south (Stasney, 2000; Nanus, 2000; Mitchell et al., 2003). In addition, the extended area supports realistic boundary conditions that suit the modeling of ground water flow (Kemblowski and Asefa, 2003a,b). The total area of the extended aquifer region is approximately 376 miles $^{2}$ and is shown in Fig. 3 along with the boundaries of the SumasBlaine Aquifer. Hereafter, the model domain or the study area will refer to the extended Sumas-Blaine aquifer as depicted in Fig. 3. There are 39 drainages representing the extended aquifer region.

Due to the intensive agricultural activities in the study area, ground water quality in the aquifer has been continuously degrading and nitrate concentrations are increasing (Almasri and Kaluarachchi, 2004b). The study area is the second in Washington State and the eighth in the US for dairy production (Stasney, 2000). The persistent elevated nitrate concentrations in ground water of the study 
area are found close to the locations of dairy farms (Almasri and Kaluarachchi, 2004c). The study area produces more than $59 \%$ of the US red raspberries ranking fifth in world raspberry production (Stasney, 2000; Gelinas, 2000). Since raspberries have a low nutrient requirement, high nitrogen addition to raspberries can result in substantial nitrate leaching to ground water. The aquifer readily interacts with surface water and serves as an important source of summer streamflows to the rivers and creeks in the study area (Tooley and Erickson, 1996). The study area supports a variety of fish species important to the cultural heritage, economy, and the ecology of the area. Since the role of nitrate in eutrophication is well-recognized, nitrate contamination of surface water is a concern as it greatly affects the fish habitat. In general, the transport of nitrate to surface water occurs mainly via discharge of ground water during baseflow conditions (Bachman et al., 2002). This is apparent for the study area since an average of $70 \%$ of streamflow comes from ground water recharge through baseflow (Kemblowski and Asefa, 2003a). This baseflow is very likely to be contaminated with nitrate. In addition, nitrogen applied in the study area is mainly in the organic form (Almasri and Kaluarachchi, 2004a) and it has to go through the processes of mineralization and nitrification in the soil zone before leaching to ground water as nitrate. The nitrate after reaching the ground water will eventually get to surface water via baseflow. Therefore, the prevention of ground water contamination from nitrate also protects surface water quality.

\subsection{Fate and transport of nitrogen}

The modeling framework depicted in Fig. 2 was developed for the extended Sumas-Blaine aquifer. It considers a high-resolution land cover distribution and land use practices to estimate the on-ground nitrogen loadings from point and non-point sources followed by a soil nitrogen model to predict the nitrogen transformations in the soil zone. The soil nitrogen transformations considered were mineralization, immobilization, nitrification, denitrification, and plant uptake. The soil nitrogen model is a lumped-parameter model similar to NLEAP. The main output from this integrated modeling approach is the monthly nitrate mass leaching to ground water. The soil nitrogen transformation model was validated using NLEAP as shown in Almasri (2003) and Almasri and Kaluarachchi (2004a). A fate and transport of nitrate in ground water was developed for the study area. The reactive mass transport model, MT3D (Zheng and Wang, 1999), was used as the simulation model which is linked to MODFLOW (Harbaugh and McDonald, 1996). A detailed description of the model development is provided by Kemblowski and Asefa (2003a), Almasri (2003), and Kaluarachchi and Almasri (2004).

A total of 56 receptors were selected (as depicted in Fig. 4) to evaluate the MCL constraints. In the selection process, consideration was given to both areas with high on-ground nitrogen loading and areas with minimal land use activities contributing to nitrogen. The selected receptors, however, have nitrate concentrations exceeding the MCL under the existing land use classes and practices. Yet, receptors with extremely high nitrate concentrations were not considered. These receptors cover 14 drainages; Fourmile, Tenmile, California, South Fork Dakota, Schneider, Lummi Peninsula West, Fishtrap, Breckenridge, Dale, Johnson, and Jordan drainages. In addition, the Canadian portions of Bertrand, Fishtrap, and Johnson drainages were selected and treated as independent drainages in this work. The selected drainages contribute the majority of the on-ground nitrogen loadings in the study area due to the high agricultural activities (Kaluarachchi and Almasri, 2004).

\subsection{Optimization analysis}

ANN development. Since there are 14 drainages selected for protection alternatives, the ANN has a total of 28 input parameters where 14 parameters correspond to the annual manure application rates and the remaining are for the annual fertilizer application rates. ANN output is the maximum monthly nitrate concentrations at the 56 receptors at the $10^{\text {th }}$ year. To generate the training and testing patterns for ANN development, the on-ground nitrogen loadings from manure and fertilizers were randomly allocated and the simulations were performed using the soil nitrogen and mass transport models (see Fig. 2) and the corresponding nitrate concentrations at the receptors were obtained. A total of 440 patterns were generated and 352 patterns were allocated to the training set and the remainder for testing. This allocation was based on a trial-and-error approach until ANN performance in the training and testing phases was the best. The ANN was developed using the Neural Works Professional II/Plus (NeuralWare ${ }^{\circledR}, 2000$ ) and the salient parameters of the ANN are summarized in Table 2. Fig. 5 shows the worst and best scatterplots for the predicted and simulated nitrate concentrations using the ANN and MT3D, respectively. A detailed description of ANN development is available in Almasri (2003).

GA development. The development of GA requires the identification of specific parameters and related concepts and these are summarized in Table 2. An important step in developing the GA framework is to ascribe the penalty coefficient, $\Omega$, described in Eq. (3). A range of penalty coefficients was considered and the performance in optimizing the on-ground nitrogen loadings was tested accordingly. Since the on-ground nitrogen loadings from manure and fertilizers are in the order of millions while the penalty term is in the order of thousands for the maximum value of $\Omega$, it is essential to make these quantities comparable; otherwise, the penalty values will be ineffective. Therefore, the loadings were scaled and $\Omega=27$ yielded the optimal performance of GA. It is important to mention that $\Omega$ was determined for the weighting coefficients $\delta_{\mathrm{M}}=\delta_{\mathrm{F}}=1.0$. Thereafter, the values of $\delta_{\mathrm{M}}$ and $\delta_{\mathrm{F}}$ have to 


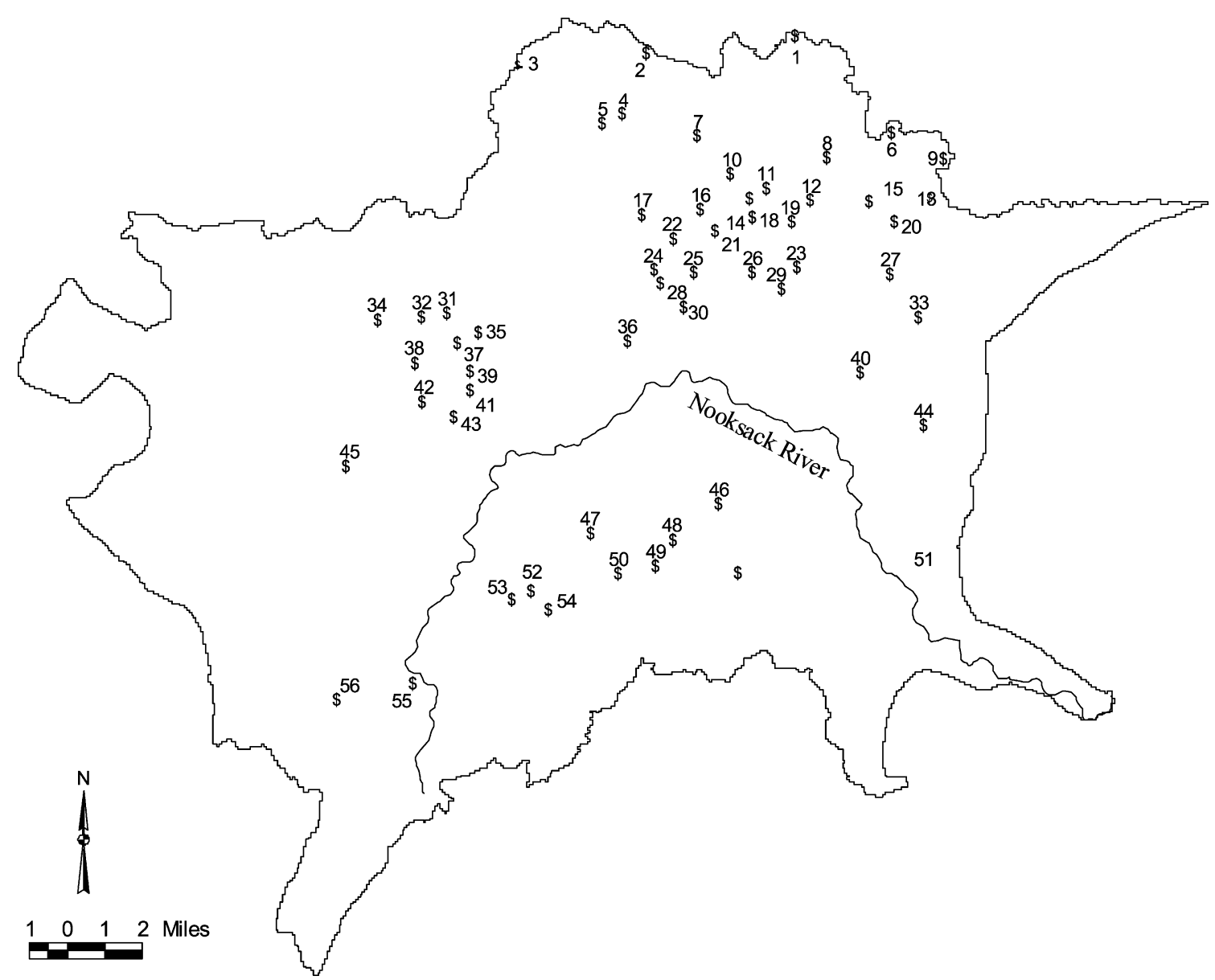

Fig. 4. The spatial distributions of the receptors selected in the study area to satisfy the MCL constraint.

be determined. Preliminary estimations of costs associated with the reductions in manure and fertilizer loadings showed that higher negative economic consequences were incurred in the case of fertilizer reduction as compared to the same reduction in manure. It was found that the optimal manure and fertilizer loadings correspond to $\delta_{\mathrm{M}}=0.5$ and $\delta_{\mathrm{M}}=2.0$.

\section{Results and discussion}

\subsection{Sustainable on-ground nitrogen loading}

Table 3 summarizes the existing and the predicted optimal or sustainable manure and fertilizer loadings for

Table 2

The key parameters and concepts used in the development of ANN and GA

\begin{tabular}{lllll}
\hline ANN & & GA & Value \\
\hline Parameter & Value & & Parameter & 28 \\
\hline Number of input nodes & 28 & Number of chromosomes & 300 \\
Number of output nodes & 56 & Population size & 0.9 \\
Number of hidden nodes & 40 & Crossover probability & 0.08 \\
Number of hidden layers & 1 & Mutation probability & 300 \\
Learning rate-hidden layer & 0.3 & Number of generations & Real value \\
Learning rate-output layer & 0.15 & Chromosome coding & Uniform \\
Momentum & 0.4 & Crossover method & 5 \\
Random seed & 257 & Selection method & 0.01 \\
Epoch & 16 & Number of elites & 27 \\
Activation function & Hyperbolic & {$[-1,+1]$} & Convergence criterion & 0.5 \\
Scaling intervals, input & {$[-0.8,+0.8]$} & Penalty coefficient & 2.0 \\
Scaling intervals, output & 50,000 & Weighting coefficient, manure & \\
Learning count & Back propagation & Weighting coefficient, fertilizer & \\
Learning algorithm & Delta-bar-delta & & \\
Learning method & & & \\
\hline
\end{tabular}



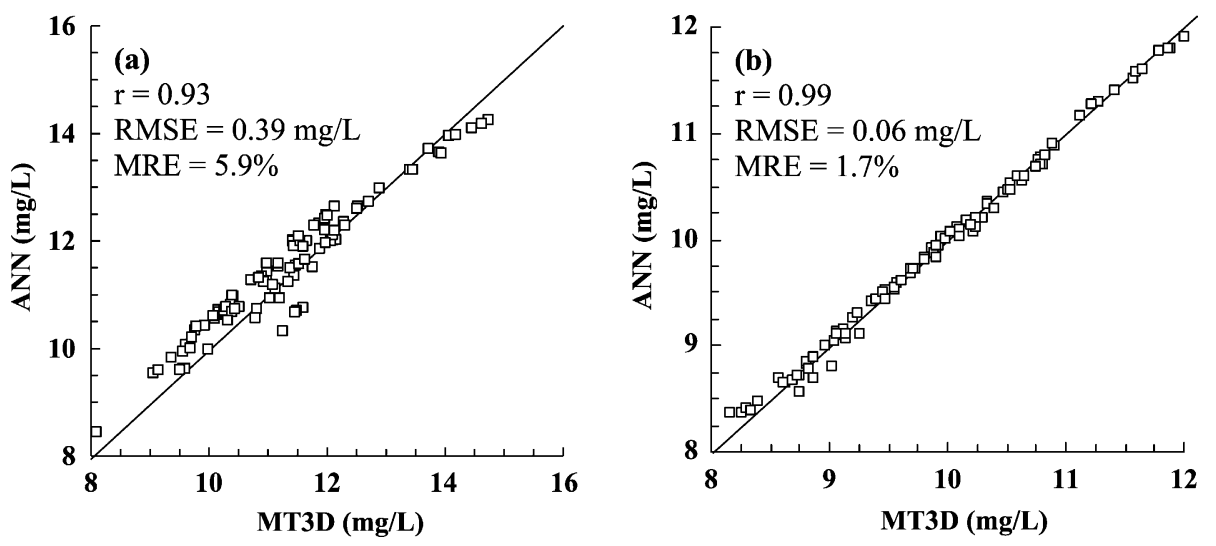

Fig. 5. Best and worst predictions of nitrate concentrations for receptors using ANN and the fate and transport model MT3D at two receptors (a) \#19, and (b) \#49.

the selected drainages. The total annual on-ground manure loadings before and after reductions are 13.6 and 10.3 million lbs- $\mathrm{N}$, respectively. The reductions in percentage vary from 13 to $42 \%$ with an overall weighted reduction percentage of $25 \%$. The highest manure loading reductions are in the Tenmile drainage followed by Schneider, Fishtrap, and the Canadian portions of Bertrand, Fishtrap, and Johnson drainages. The total annual on-ground fertilizer loadings before and after reductions are 2.3 and 2.1 million lbs-N, respectively. The reduction percentages varied from 0 to $29 \%$ with an overall weighted reduction percentage of $14 \%$. It is noted that the highest fertilizer loading reductions are required in the Canadian portions of Bertrand, Fishtrap, and Johnson drainages.

Fig. 6 shows the maximum nitrate concentrations at the receptors due to the existing and predicted sustainable loadings at the $10^{\text {th }}$ year of simulation. It is seen from Fig. 6 that the nitrate concentrations are maintained below the MCL with the application of the predicted sustainable onground nitrogen loading. It is worthwhile to mention that many receptor concentrations are close to the MCL signifying a tight constraint while others are notably below. This observation can be attributed to the fact that the existing manure and fertilizer loadings yield different nitrate concentrations. Since the decision variables are defined at the drainage level assuming uniform loadings, receptors currently with high nitrate concentrations require more loading reduction than others. This observation implies that high loading reductions are incurred to satisfy the MCL constraint at receptors with high nitrate concentrations although other receptors may not require this high level of reduction.

\subsection{Decision analysis}

In order to maintain the actual on-ground manure and fertilizer loadings in compliance with the predicted sustainable loadings given in Table 3 , nine protection alternatives were evaluated and these alternatives are summarized in Table 4. For instance, alternative 2

Table 3

Existing and predicted sustainable on-ground nitrogen loadings for manure and fertilizers for the selected drainages along with the percentages of loading reductions

\begin{tabular}{|c|c|c|c|c|c|c|}
\hline \multirow[t]{2}{*}{ Drainage } & \multicolumn{3}{|c|}{ Manure loading $\left(\times 10^{6} \mathrm{~N}\right.$ lbs/year $)$} & \multicolumn{3}{|c|}{ Fertilizer loading $\left(\times 10^{6} \mathrm{~N}\right.$ lbs/year $)$} \\
\hline & Existing & Sustainable & Reduction (\%) & Existing & Sustainable & Reduction (\%) \\
\hline Fourmile & 0.410 & 0.319 & 22 & 0.060 & 0.060 & 0 \\
\hline Tenmile & 1.070 & 0.619 & 42 & 0.124 & 0.103 & 17 \\
\hline California & 0.653 & 0.523 & 20 & 0.110 & 0.110 & 0 \\
\hline South Fork Dakota & 1.376 & 1.040 & 24 & 0.032 & 0.032 & 0 \\
\hline Schneider & 0.159 & 0.115 & 28 & 0.083 & 0.083 & 0 \\
\hline Lummi Peninsula & 0.085 & 0.069 & 18 & 0.028 & 0.028 & 0 \\
\hline \multicolumn{7}{|l|}{ West } \\
\hline Fishtrap & 1.838 & 1.345 & 27 & 0.346 & 0.332 & 4 \\
\hline Breckenridge & 2.347 & 1.750 & 25 & 0.107 & 0.095 & 11 \\
\hline Dale & 0.694 & 0.567 & 18 & 0.090 & 0.090 & 0 \\
\hline Johnson & 1.344 & 1.105 & 18 & 0.222 & 0.160 & 28 \\
\hline Jordan & 0.359 & 0.311 & 13 & 0.032 & 0.030 & 4 \\
\hline Bertrand (Canada) & 1.516 & 1.125 & 26 & 0.327 & 0.231 & 29 \\
\hline Fishtrap (Canada) & 1.406 & 1.093 & 22 & 0.304 & 0.240 & 21 \\
\hline Johnson (Canada) & 0.391 & 0.296 & 24 & 0.084 & 0.075 & 11 \\
\hline
\end{tabular}




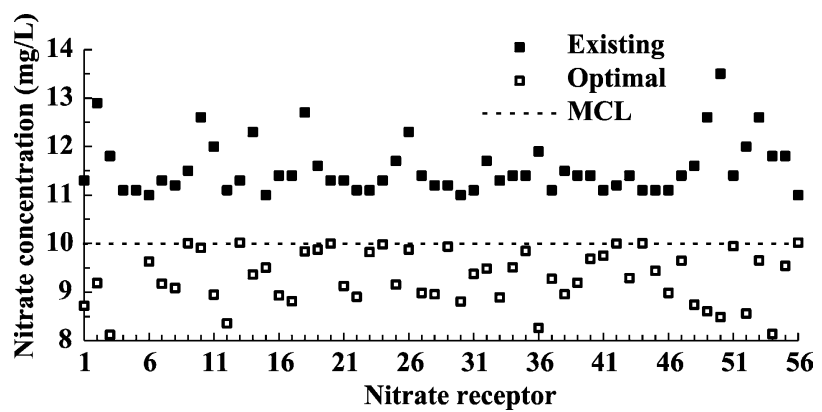

Fig. 6. Maximum nitrate concentration at the receptors for existing and predicted sustainable on-ground nitrogen loadings at the $10^{\text {th }}$ year of simulation.

downsizes the cattle herds in the selected drainages proportional to the percentages of reduction in manure loadings given in Table 3. For example, the required manure loading reduction is $22 \%$ in the Fourmile drainage to satisfy the sustainable loading. Therefore, a $22 \%$ reduction in the herd size may be needed. Although alternatives 1, 5, and 6 have no direct influence on the optimal solution, these alternatives were investigated as these alternatives are common. Qualitatively, Table 5 summarizes the effectiveness of each alternative in meeting the MCL constraint as well as the potential capability in reducing the on-ground nitrogen loading from manure and fertilizer applications as required by the optimal solution. For instance, alternative 1 , do nothing, does not address the MCL constraint or affect the on-ground nitrogen loading therefore it was given the symbol ' $X$ '. On the other hand, alternative 5, adopt a feeding strategy for dairy cattle, reduces nitrogen loading from manure by $14 \%$ and therefore this alternative addresses manure loading reduction and hence given the symbol ' $\checkmark$ '. Nevertheless, adopting alternative 5 is not sufficient to reduce the existing manure loading to the sustainable loading as indicated by Table 3 where it is clear that many drainages require reduction percentages beyond the $14 \%$ that can be achieved via alternative 5 . Later in this manuscript, the alternatives will be evaluated quantitatively per each criterion.

The protection alternatives were also analyzed for time-series of nitrate concentration at receptors 20 and 42 .
Fig. 7 shows that alternatives 7 and 9 are the only protection alternatives that meet the MCL constraint for receptor 20 . The time-series of nitrate concentration show a transient behavior at the end of the simulation period signifying that a further reduction in nitrate concentration can be expected upon the continuation of alternatives 7 or 9 . These alternatives signify the necessity of combining different alternatives to meet the MCL constraint at the receptors. Apparently, fertilizer reduction denoted by alternative 4 is not effective, yet this alternative has a supporting impact when combined with alternative 3 . Protection alternatives simulated at receptor 42 (see Fig. 8) located in a dairy farm area in the South Fork Dakota drainage show a different behavior of nitrate concentration as compared to those at receptor 20 (see Fig. 7). First, the time-series of nitrate concentration reach a quasi-steady state. Second, reducing manure loading achieved by alternatives 2 or 3 satisfies the MCL constraint. Since this drainage does not require a reduction in fertilizer loading (see Table 3 ), alternatives 4 , 6,7 , and 9 are not technically needed. It can be concluded that a specific protection alternative may be effective at some receptors, but may not be effective at others. The effectiveness or the applicability of a protection alternative depends mainly on the spatial location of the receptor and the nitrogen source contributing to the on-ground nitrogen loading in the surrounding area of the receptor.

\subsubsection{Economic costs}

Although the economic cost analysis of different proposed protection alternatives is an important step, this is also the most difficult decision criterion to evaluate because the analysis requires a close examination of the prevailing conditions in the study area. Since many cost components vary (see Table 6), COST and consequently CPCR values were calculated stochastically using the Monte Carlo method. The net present values of each alternative at the end of the ten year simulation period are summarized in Table 4. This section presents a brief discussion of the cost incurred due to the implementing of the protection alternatives.

Do-nothing alternative. In the study area, no-actions were taken to restore the contaminated ground water from

Table 4

Summary description of the protection alternatives and the net present value of each alternative cost at the end of the 10-year simulation period

\begin{tabular}{|c|c|c|}
\hline ID & Description & Cost $\left(\times 10^{6} \$\right)$ \\
\hline Alternative 1 & Do-nothing (maintain current loadings) & 0 \\
\hline Alternative 2 & Dairy cattle herd reduction & 43.8 \\
\hline Alternative 3 & Manure composting/exporting & 8.7 \\
\hline Alternative 4 & Fertilizer application reduction & 12.3 \\
\hline Alternative 5 & Adopt a feeding strategy for dairy cattle & -1.7 \\
\hline Alternative 6 & Adopt a feeding strategy for dairy cattle + fertilizer application reduction & 10.6 \\
\hline Alternative 7 & Manure composting/exporting + fertilizer application reduction & 21.0 \\
\hline Alternative 8 & Manure composting/exporting + adopt a feeding strategy for dairy cattle & 2.10 \\
\hline Alternative 9 & $\begin{array}{l}\text { Manure composting/exporting }+ \text { fertilizer application reduction }+ \text { adopt a feeding } \\
\text { strategy for dairy cattle }\end{array}$ & 14.4 \\
\hline
\end{tabular}


Table 5

Effectiveness of different alternatives in satisfying the MCL constraint as well as the on-ground source types addressed by each alternative

\begin{tabular}{llll}
\hline ID & Meeting MCL & Manure & Fertilizer \\
\hline Alternative 1 & $\times$ & $\times$ & $\times$ \\
Alternative 2 & $\times$ & $\checkmark$ & $\times$ \\
Alternative 3 & $\times$ & $\checkmark$ & $\times$ \\
Alternative 4 & $\times$ & $\times$ & $\checkmark$ \\
Alternative 5 & $\times$ & $\checkmark$ & $\times$ \\
Alternative 6 & $\times$ & $\checkmark$ & $\checkmark$ \\
Alternative 7 & $\checkmark$ & $\checkmark$ & $\checkmark$ \\
Alternative 8 & $\times$ & $\checkmark$ & $\times$ \\
Alternative 9 & $\checkmark$ & $\checkmark$ & $\checkmark$ \\
\hline
\end{tabular}

nitrate and no search for alternative water sources were made. As such, it was assumed that no economic ramifications would be encountered from this alternative. Yet, restoring the ground water from nitrate contamination is the policy of the decision-makers such that no increasing trend in nitrate concentrations should be allowed.

Dairy cattle herd reduction. The basic premise in estimating the cost of this protection alternative is to estimate the loss of benefits incurred due to the reduction in milk production. The average milk production per cow in the study area ranges from 20,968 to 22,324 lbs and the net annual income per cow ranges from $\$ 715$ to $\$ 746$. An assumption was made that dairy herd is reduced or downsized by selling a portion of the herd in proportion with the required reduction percentages in manure loading of each drainage. In addition, a one-time profit was expected from selling the required part of the herd.

Manure composting/exporting. The net cost of this protection alternative considers the cost of composting manure, savings from the reduction in manure spreading, and the savings from marketing the composted manure. The total composting cost equals the compostable manure weight (tons) multiplied by the composting cost (\$/ton). Manure composting cost for the study area equals to $\$ 10.80 /$ ton. The annual manure spreading cost was computed assuming that the average annual cost of manure spreading ranges from $\$ 25$ to $\$ 77$ per cow and that the daily

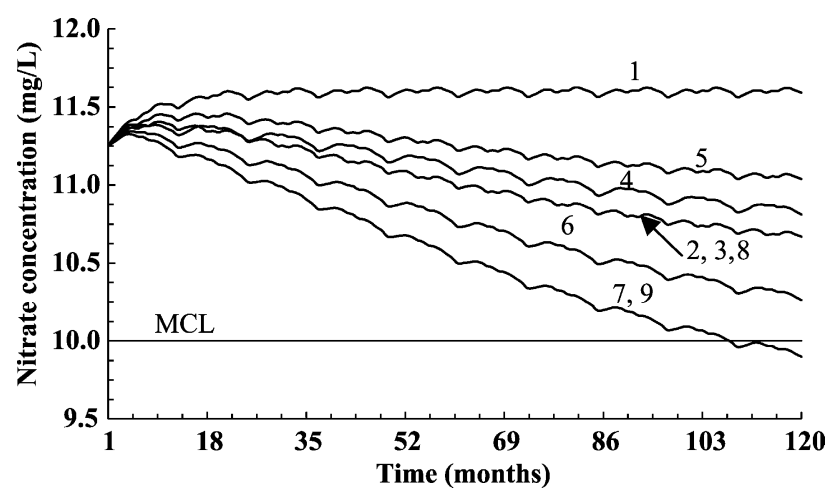

Fig. 7. Time-series of nitrate concentrations at receptor \#20 for the proposed protection alternatives. This receptor is located in a pasture area in Johnson drainage. Alternative numbers are as defined in Table 4.

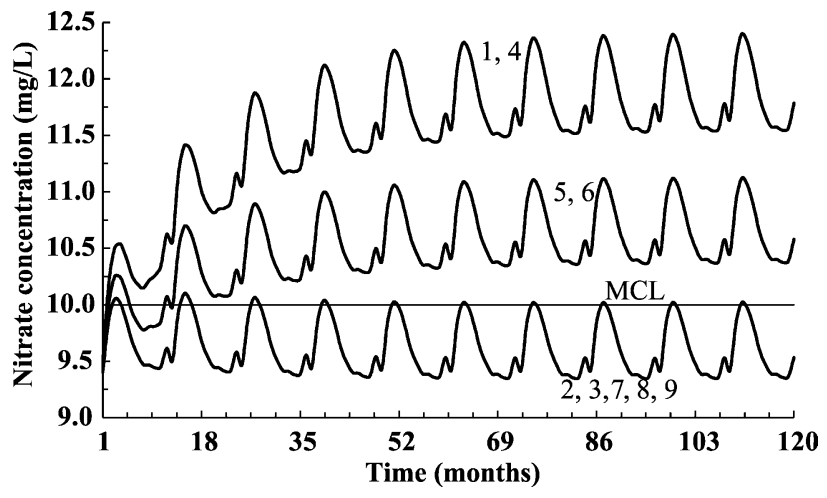

Fig. 8. Time-series of nitrate concentrations at receptor \#42 for selected protection alternatives. This receptor is located in a dairy farm area in South Fork Dakota drainage. Alternative numbers are as defined in Table 4.

manure production is $115 \mathrm{lbs}$ per cow. The composted manure can be soled from the farm at a rate of $\$ 25$ per yard $^{3}$ or $\$ 13.50 /$ ton.

Fertilizer application reduction. The economic analysis associated with fertilizer application reduction involves savings from the decrease in the fertilizer purchased and the possible loss due to a proposed decline in crop yield. The benefits from fertilizer application reduction are estimated by multiplying the weight of the reduced fertilizers (lbs-N) with the corresponding unit cost of nitrogen-based fertilizers, which equals $\$ 0.237$ per lb-nitrogen. Regarding the estimation of possible loss in crop yield, there was no research conducted for the study area to estimate the cost due to the loss in crop yield with the reduction in fertilizer application rates. Yadav and Wall (1998) showed that a 21\% reduction of fertilizer application rate on cornfields did not

Table 6

Probability density functions of cost-related parameters

\begin{tabular}{|c|c|c|}
\hline Parameter & $\begin{array}{l}\text { Distribution } \\
\text { type }\end{array}$ & $\begin{array}{l}\text { Distribution } \\
\text { bounds }\end{array}$ \\
\hline Manure spreading cost $(\$ /$ cow $)$ & Triangle & {$[25,77,50]$} \\
\hline $\begin{array}{l}\text { Composted manure revenue } \\
(\$ / \text { ton })\end{array}$ & Uniform & {$[0,13.5]^{\mathrm{a}}$} \\
\hline $\begin{array}{l}\text { Milk production (lbs/milking } \\
\text { cow) }\end{array}$ & Uniform & $\begin{array}{l}{[20,968} \\
22,324]\end{array}$ \\
\hline $\begin{array}{l}\text { Dairy net annual income } \\
\text { (\$/milking cow) }\end{array}$ & Uniform & {$[715,746]$} \\
\hline $\begin{array}{l}\text { Price of milking cows ( } \$ / 100 \mathrm{lbs} \\
\text { weight) }\end{array}$ & Triangle & {$[59.5,65.8,62.2$} \\
\hline $\begin{array}{l}\text { Price of dry cows ( } \$ / 100 \mathrm{lbs} \\
\text { weight) }\end{array}$ & Triangle & {$[59.5,65.8,62.2$} \\
\hline $\begin{array}{l}\text { Price of heifers ( } \$ / 100 \mathrm{lbs} \\
\text { weight) }\end{array}$ & Triangle & {$[63.5,70.1,66.8$} \\
\hline $\begin{array}{l}\text { Price of calves }(\$ / 100 \mathrm{lbs} \\
\text { weight) }\end{array}$ & Triangle & {$[89.1,104,94.8]$} \\
\hline $\begin{array}{l}\text { Crop yield loss for a } 20 \% \\
\text { fertilizer reduction }(\%)\end{array}$ & Uniform & {$[0,10]$} \\
\hline
\end{tabular}

Distribution bounds are defined as [min,max,likeliest] for triangular distributions and [min,max] for uniform distributions.

${ }^{a}$ There is a probability that dairy farmers may not be able to sell composted manure at full price and may be compelled to distribute it free of charge or at a reduced price. 

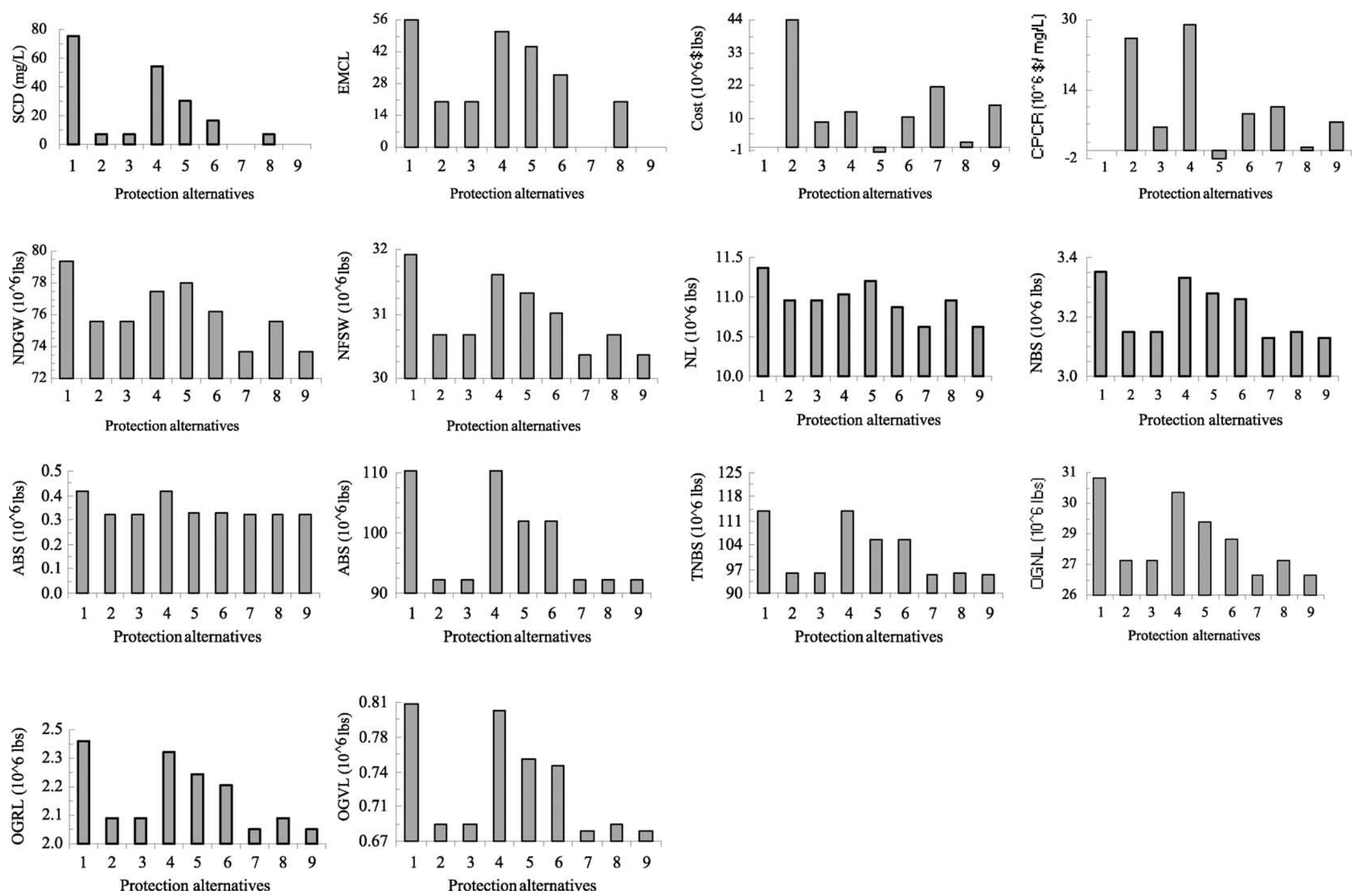

Fig. 9. An illustrative representation of the different criteria computed for the different protection alternatives. Acronyms are defined in Table 1. 
result in a crop yield loss. Puckett et al. (1999) cited many studies that estimated fertilizer applications in the US to be 24 to $38 \%$ higher than the crop demand. On the other hand, many farmers apply fertilizers at the optimal rate that is close to the point of diminishing returns defined on the curve of the fertilizer quantity versus crop yield. Such an application strategy implies a maximum reduction of $10 \%$ in crop yield for a $20 \%$ reduction in fertilizer application rate. As such, a range from 0 to $10 \%$ was assumed for possible loss in crop yield for $20 \%$ fertilizer reduction. Linear interpolation and extrapolation was followed to compute the possible loss in yield for different fertilizer reduction percentages. The net revenue per acre (\$/acrecrop) was obtained for the main crops in the study area for 1999-2001.

Improving cow diet. Here it was assumed that no reduction in milk production or its quality occured due to the adoption of this alternative and farmers would save $\$ 0.50$ per cow per month (Jonker et al., 2002). Apparently, this approach yields economic benefits to the dairy farm owners.

Combined protection alternatives. The costs of combined alternatives were computed by summing the annual costs of each individual alternative. For alternatives 8 and 9 which correspond to manure composting/exporting and feeding, the costs were calculated by considering that the feeding strategy reduces the nitrogen content by $14 \%$ in manure while manure composting/exporting reduces the remainder of the nitrogen content.

\subsubsection{Estimates of decision criteria}

Decision criteria were computed for the protection alternatives as shown in Fig. 9. Table 7 summarizes the normalized criteria where a zero value signifies the lowest influence on the best score of the total utility of a specific alternative. Apparently, alternatives 7 and 9 are the most effective alternatives satisfying the MCL constraint. Alternative 5 is the most economic alternative since dairy farmers gain benefits (negative costs) by reducing the crude protein. Also, alternative 5 has the lowest CPCR value as well. The CPCR value for alternative 8 is low when considering that this alternative is economically and environmentally effective. Not surprisingly, reducing dairy herd size, alternative 2, has the most severe economic impacts, yet environmentally effective as alternative 3 . Although not shown here, five receptors did meet the MCL constraint for alternative 4 and SCD was reduced from 75 to $54 \mathrm{mg} / \mathrm{L}$. When alternative 4 was combined with alternative 3 , no receptor exceeded the MCL while for alternative 3, a total of 20 receptors exceeded the MCL. As expected, alternatives 7 and 9 produced the lowest nitrate mass buildup in soil and ground water, lowest mass flux to surface water bodies, and the lowest nitrate leaching from soil while the worst among all criteria is the do-nothing alternative. The highest on-ground nitrogen loading and nitrogen losses via runoff and volatilization correspond to alternatives 1 and 4 while the lowest corresponds to alternatives 7 and 9 .

\subsubsection{Ranking of protection alternatives}

The final step in the decision analysis is the use of the IOC method for ranking the protection alternatives (see Fig. 1). The decision criteria were normalized (see Table 7) and the importance order of the decision criteria was specified and accordingly ranked as summarized in the first column of Table 7. The ranking of the decision criteria is such that the criteria pertinent to the constraint of the nitrate concentration were given the highest preference or priority over the remaining criteria. Nevertheless, the economic cost of a protection alternative was given the subsequent priority. Next, Eq. (9) was used to compute the utility scores and the best and worst scores were computed according to Eqs. (10) and (11). Fig. 10 shows the best, average, and worst utility scores for each protection alternative. It is worth noting that the spread of the best and worst utility scores signifies the sensitivity to the weight vectors consistent with the importance order of the criteria (Yakowitz et al., 1993).

Table 7

Summary of normalized utility values of each protection alternative for different decision criteria based on the importance order of criteria

\begin{tabular}{|c|c|c|c|c|c|c|c|c|c|c|}
\hline $\begin{array}{l}\text { Importance } \\
\text { order }\end{array}$ & Criteria & $\begin{array}{l}\text { Alternative } \\
1\end{array}$ & $\begin{array}{l}\text { Alternative } \\
2\end{array}$ & $\begin{array}{l}\text { Alternative } \\
3\end{array}$ & $\begin{array}{l}\text { Alternative } \\
4\end{array}$ & $\begin{array}{l}\text { Alternative } \\
5\end{array}$ & $\begin{array}{l}\text { Alternative } \\
6\end{array}$ & $\begin{array}{l}\text { Alternative } \\
7\end{array}$ & $\begin{array}{l}\text { Alternative } \\
8\end{array}$ & $\begin{array}{l}\text { Alternative } \\
9\end{array}$ \\
\hline 1 & SCD & 0 & 0.905 & 0.905 & 0.280 & 0.599 & 0.780 & 1 & 0.905 & 1 \\
\hline 2 & EMCL & 0 & 0.643 & 0.643 & 0.089 & 0.214 & 0.429 & 1 & 0.643 & 1 \\
\hline 3 & COST & 0.963 & 0 & 0.771 & 0.693 & 1 & 0.730 & 0.500 & 0.917 & 0.646 \\
\hline 4 & CPCR & 0.936 & 0.099 & 0.769 & 0 & 1 & 0.665 & 0.615 & 0.907 & 0.726 \\
\hline 5 & NBGW & 0 & 0.673 & 0.673 & 0.324 & 0.237 & 0.563 & 1 & 0.673 & 1 \\
\hline 6 & NFSW & 0 & 0.802 & 0.802 & 0.201 & 0.381 & 0.582 & 1 & 0.802 & 1 \\
\hline 7 & NL & 0 & 0.553 & 0.553 & 0.447 & 0.216 & 0.663 & 1 & 0.553 & 1 \\
\hline 8 & NBS & 0 & 0.911 & 0.911 & 0.089 & 0.326 & 0.415 & 1 & 0.911 & 1 \\
\hline 9 & ABS & 0 & 1 & 1 & 0 & 0.892 & 0.892 & 1 & 1 & 1 \\
\hline 10 & OBS & 0 & 1 & 1 & 0 & 0.463 & 0.463 & 1 & 1 & 1 \\
\hline 11 & TNBS & 0 & 0.999 & 0.999 & 0.001 & 0.463 & 0.464 & 1 & 0.999 & 1 \\
\hline 12 & OGNL & 0 & 0.845 & 0.845 & 0.155 & 0.453 & 0.622 & 1 & 0.845 & 1 \\
\hline 13 & OGRL & 0 & 0.875 & 0.875 & 0.125 & 0.375 & 0.500 & 1 & 0.875 & 1 \\
\hline 14 & OGVL & 0 & 0.948 & 0.948 & 0.052 & 0.426 & 0.478 & 1 & 0.948 & 1 \\
\hline
\end{tabular}




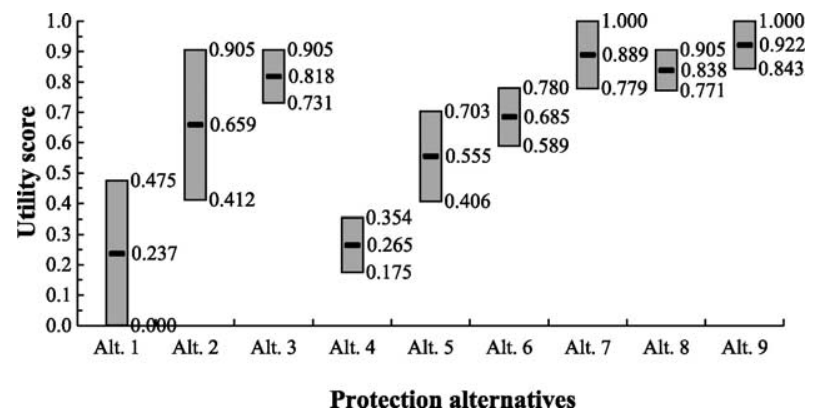

Fig. 10. Best, average, and worst utility scores for the different protection alternatives.

Recalling the description of the IOC method discussed earlier, it is obvious from Fig. 10 that no protection alternative dominates over the other alternatives. As such, the ranking of the protection alternatives was accomplished by the use of the average utility scores as summarized in Table 8.

As anticipated (see Fig. 9 and Table 7), the results show that alternatives 7 and 9 are the best alternatives based on the average, best, and worst utility scores. Alternatives 8 and 3 attained the third and fourth places, respectively, in the three ranking schemes. Alternatives 1 and 4 exchanged the last two positions suggesting a low preference for the current order of decision criteria. Nevertheless, alternative 7 , which is a combination of alternatives 3 and 4, produced an effective alternative. Although improving cow diets, alternative 5, has the lowest cost, it occupied the seventh place when considering the average utility scores due to its ineffectiveness in satisfying the MCL constraint.

\section{Summary and conclusions}

The methodology described here focused on developing an integrated approach combining nitrogen loading, physical processes, and decision analysis for the optimal management of nitrate contamination of ground water. The methodology introduced several important concepts in decision analysis pertinent to the management of

Table 8

Rankings of the protection alternatives for the best, average, and worst utility scores

\begin{tabular}{llll}
\hline Ranking & \multicolumn{2}{l}{ Utility score } & \\
\cline { 2 - 4 } & Average & Best & Worst \\
\hline 1 & Alternative 9 & Alternative 9 & Alternative 9 \\
2 & Alternative 7 & Alternative 7 & Alternative 7 \\
3 & Alternative 8 & Alternative 8 & Alternative 8 \\
4 & Alternative 3 & Alternative 3 & Alternative 3 \\
5 & Alternative 6 & Alternative 2 & Alternative 6 \\
6 & Alternative 2 & Alternative 6 & Alternative 5 \\
7 & Alternative 5 & Alternative 5 & Alternative 2 \\
8 & Alternative 4 & Alternative 1 & Alternative 4 \\
9 & Alternative 1 & Alternative 4 & Alternative 1 \\
\hline
\end{tabular}

subsurface pollution. The proposed methodology relies on determining the sustainable on-ground nitrogen loading distribution such that nitrate concentrations at selected receptors are below the MCL. The proposed approach depicted in Fig. 1 integrates on-ground nitrogen loadings from different sources, soil nitrogen dynamics, ground water flow, fate and transport in ground water, and an optimization framework to determine the sustainable onground nitrogen loading distribution, and a multi-criteria decision analysis to prioritize proposed protection alternatives. The protection alternatives are introduced to reduce the current nitrogen loadings to match the predicted sustainable loadings. Decision criteria are developed to account for economic and environmental consequences and the IOC method was utilized to rank the alternatives. The applicability and practicability of the proposed methodology was successfully demonstrated for the area encompassing the Sumas-Blaine aquifer located in Washington State.

The conceptual model depicted in Fig. 2 allowed for the proper simulation of the outcome of the protection alternatives. Results showed that ANN successfully predicted the soil nitrogen dynamics and ground water fate and transport processes. GA was effective in the search process for the optimal or the sustainable loadings. The IOC method is a straightforward and an efficient method to prioritize the alternatives. Apparently, managing the manure loading has a high impact on nitrate concentration reduction as compared to the fertilizer loading reduction. Therefore, it is not efficient to automatically reduce the fertilizer application and assume this alternative to be effective without the proper assessment via mathematical simulation models. In a broad sense, specific protection alternatives may be efficient to reduce nitrate concentration at some receptors but may not be efficient for others. This assessment depends on the spatial location of the receptors and the overall on-ground nitrogen source types and corresponding loadings in the contributing area. Combining different protection alternatives proved to be indispensable to satisfy the MCL constraint. The ranking of protection alternatives does not indicate an absolute decision but merely reflects the outcome of the optimization analysis, the weighting coefficients in the objective function, the spatial distribution of the receptors, and the ranking order of the decision criteria.

The sustainable on-ground manure and fertilizer loadings obtained from the implementation of the methodology are only preliminary and should provide insight for a more exhaustive and comprehensive strategy for nitrate pollution management. The results from this study can provide introductory assessments of possible protection alternatives and the corresponding economic consequences, and present a general trend needed in the on-ground nitrogen loading reduction.

The methodology has limitations that should be addressed. The overall management problem can be 
classified as an inverse problem. For instance, given that the nitrate concentrations at the receptors have to be less than or equal the MCL, what are the maximum on-ground nitrogen loadings from manure and fertilizers that can satisfy the MCL constraint? The answer to this question is that there is no unique solution and with increasing the number of drainages (decision variables) the degree of non-uniqueness increases. A second limitation of this methodology is that the decision variables are made at the drainage level. This coarse resolution can lead to an unnecessary reduction in loadings in some areas and produce receptors with highly relaxed constraints while others are not (see Fig. 6). Since the sustainable loadings are uniform over a drainage, there will be serious economic consequences in enforcing a reduction in loadings in areas where there are no concentrations exceeding the MCL. Another limitation is that ANN training is time-consuming especially for large areas and may have to be repeated if additional receptors are to be introduced or additional drainages to be considered. Additional work to assess the uncertainty of model parameters may be needed to obtain better insight into the methodology.

\section{References}

Almasri, M.N., 2003. Optimal management of nitrate contamination of ground water. PhD Dissertation, Utah State University, Logan, Utah, 229 pp.

Almasri, M.N., Kaluarachchi, J.J., 2004a. Implications of on-ground nitrogen loading and soil transformations on ground water quality management. Journal of the American Water Resources Association (JAWRA) 40 (1), 165-186

Almasri, M.N., Kaluarachchi, J.J., 2004b. Assessment and management of long-term nitrate pollution of ground water in agriculture-dominated watersheds. Journal of Hydrology 295, 225-245.

Almasri, M.N., Kaluarachchi, J.J., 2004c. Modular neural networks to predict the nitrate distribution in ground water using the on-ground nitrogen loading and recharge data. Environmental Modelling and Software 2004; in press.

Aly, A.H., Peralta, R.C., 1999. Optimal design of aquifer cleanup systems under uncertainty using a neural network and a genetic algorithm. Water Resources Research 35 (8), 2523-2532.

Bachman, L.J., Krantz, D.E., Böhlke, J., 2002. Hydrogeologic framework, ground-water, geochemistry, and assessment of $\mathrm{N}$ yield from base flow in two agricultural watersheds. US Environmental Protection Agency, Kent County, MD. EPA/600/R-02/008, 46 pp.

Davis, J., Koenig, R., Flynn, R., 1999. Manure best management practices: a practical guide for dairies in Colorado, Utah, and New Mexico. Utah State University Extension, Logan, Utah. AG-WM-04, 7 pp.

Erickson, D. 1992. Ground water quality assessment, Whatcom County dairy lagoon \#2, Lynden, Washington. Open-File Report. Washington State Department of Ecology, 26 pp.

Gelinas, S. 2000. An exploratory statistical analysis of ground water quality in the Abbotsford-Sumas Aquifer. Unpublished MS thesis, Western Washington University, Bellingham, Washington, $44 \mathrm{pp}$.

Goldberg, D.E., 1989. Genetic Algorithms in Search, Optimization, and Machine Learning. Addison-Wesley, Reading, MA. 412 pp.

Harbaugh, A.W., McDonald, M.G., 1996, User's documentation for MODFLOW-96, an update to the US Geological Survey modular finite-difference ground-water flow model: US Geological Survey Open-File Report 96-485, 56 pp.

Harter, T., Davis, H., Mathews, M., Meyer, R., 2002. Shallow groundwater quality on dairy farms with irrigated forage crops. Journal of Contaminant Hydrology 55, 287-315.

Haykin, S., 1994. Neural networks: a comprehensive foundation. Maxwell Macmillan International, New York. 696 pp.

Hubbard, R.K., Sheridan, J.M., 1994. Nitrates in groundwater in the Southeastern USA, in: Adriano, D.C., Iskandar, A.K., Murarka, I.P. (Eds.), Contamination of Groundwaters. Science Reviews, Northwood, UK, pp. 303-345.

Jonker, J.S., Kohn, R.A., Hight, J., 2002. Use of milk urea nitrogen to improve dairy cow diets. Journal of Dairy Science 85, 939-946.

Kaluarachchi, J.J., Almasri, M.N., 2004. A mathematical model of fate and transport of nitrate for the extended Sumas-Blaine Aquifer, Whatcom County, Washington. Phase III Report, Utah State University, Logan, Utah, 147 pp.

Kemblowski, M., Asefa, T., 2003. Groundwater modeling of the lowlands of WRIA 1 watersheds. Draft Report, Utah State University, Logan, Utah, version 1 .

Kemblowski, M., Asefa, T., 2003. Groundwater modeling of the lowlands of WRIA 1 watersheds. Draft Report, Utah State University, Logan, Utah, version 2.

Ma, L., Shaffer, M.J., 2001. A review of carbon and N processes in nine US soil N dynamics models, in: Shaffer, M.J., Ma, L., Hansen, S. (Eds.), Modeling Carbon and N Dynamics for Soil Management. Lewis, Florida, pp. 55-102.

MacQuarrie, K.T.B., Sudicky, E., Robertson, W.D., 2001. Numerical simulation of a fine-grained denitrification layer for removing septic system nitrate from shallow groundwater. Journal of Hydrology $52,29-55$.

McGechan, M.B., Wu, L., 2001. A review of carbon and N processes in European soil N dynamics models, in: Shaffer, M.J., Ma, L., Hansen, S. (Eds.), Modeling Carbon and N Dynamics for Soil Management. Lewis, Florida, pp. 103-171.

Meisinger, J.J., Randall, G.W., 1991. Estimating N budgets for soil-crop systems, in: Follet, R.F., Keeney, D.R., Cruse, R.M. (Eds.), Managing N for Groundwater Quality and Farm Profitability. Soil Science Society of America, Madison, WI, pp. 85-124.

Mitchell, R.J., Babcock, R.S., Gelinas, S., Nanus, L., Stasney, D.E., 2003. Nitrate distributions and source identification in the Abbotsford-Sumas aquifer, Northwestern Washington State. Journal of Environmental Quality 32, 789-800.

Morshed, J., Kaluarachchi, J.J., 1998. Parameter estimation using artificial neural network and genetic algorithm for free-product migration and recovery. Water Resources Research 34 (5), 1101-1113.

Nanus, L., 2000. Spatial and temporal variability of nitrate contamination in the Abbotsford-Sumas Aquifer. MS thesis, Western Washington University, Bellingham, Washington.

National Research Council (NRC), 1989.Anon., 1989. Nutrient requirements of dairy cattle, 6th revised ed. National Academic Sciences, Washington, DC. 168 pp.

NeuralWare, 2000.Anon., 2000. Neural Computing, Using NeuralWorks, and Reference guide. NeuralWare, Pittsburg.

Newman, D.G., 1976. Engineering economic Analysis. Engineering Press, Sam Jose, CA. 469 pp.

Pace, M.G., Miller, B.E., Farrell-Poe, K.L., 1995. The composting process. Utah State University Extension. AG-WM 01, 2 pp.

Puckett, L.J., Cowdery, T.K., Lorenz, D.L., Stoner, J.D., 1999. Estimation of nitrate contamination of an agro-ecosystem outwash aquifer using a nitrogen mass-balance budget. Journal of Environmental Quality 25, 2015-2025.

Ramanarayanan, T.S., Storm, E.D., Smolen, M.D., 1998. Analysis of N management strategies using EPIC. Journal of the American Water Resources Association 34 (5), 1199-1211. 
Schilling, K.E., Wolter, C.F., 2001. Contribution of base flow to nonpoint source pollution loads in an agricultural watershed. Ground Water 39 (1), 49-58.

Shaffer, M.J., Halvorson, A.D., Pierce, F.J., 1991. Nitrate leaching and economic analysis package (NLEAP): model description and application, in: Follet, R.F., Keeney, D.R., Cruse, R.M. (Eds.), Managing N for Groundwater Quality and Farm Profitability. Soil Science Society of America, Madison, WI, pp. 285-322.

Stasney, D. 2000. Hydrostratigraphy, groundwater flow and nitrate transport within the Abbotsford-Sumas Aquifer, Whatcom County, Washington. Unpublished MS thesis, Western Washington University, Bellingham, Washington, $49 \mathrm{pp}$.

Tesoriero, A.J., Voss, F.D., 1997. Predicting the probability of elevated nitrate concentrations in the Puget Sound Basin: implications for aquifer susceptibility and vulnerability. Ground Water 35 (6), 10291039.

Tooley, J., Erickson, D., 1996. Nooksack watershed surficial aquifer characterization, Ecology Report \#96-311. Washington State Department of Ecology, Olympia, Washington. 12 pp.
US Environmental Protection Agency, 2000. Drinking water standards and health advisories. US Environmental Protection Agency, Office of Water, 822-B-00-001, $12 \mathrm{pp}$

Van Horn, H.H., 1992. Recycling manure nutrients to avoid environmental pollution, in: Van Horn, H.H., Wilcox, C.J. (Eds.), Large Dairy Herd Management. American Dairy Science Association, Champaign, IL, pp. 640-654.

Yadav, S.N., Wall, D.B., 1998. Benefit-cost analysis of best management practices implemented to control nitrate contamination of groundwater. Water Resources Research 34 (3), 497-504.

Yakowitz, D.S., Lane, L.J., Szidarovszky, F., 1993. Multi-attribute decision-making: dominance with respect to an importance order of the attributes. Applied Mathematics and Computation 54 (6), 167-181.

Zheng, C., Wang, P.P., 1999. MT3DMS, a modular three-dimensional multi-species transport model for simulation of advection, dispersion and chemical reactions of contaminants in groundwater systems; documentation and user's guide. US Army Engineer Research and Development Center Contract Report SERDP-99-1, Vicksburg, Mississippi, 169 pp. 